\title{
Tectonic Creep in the
}

\section{Hayward Fault Zone}

\section{California}

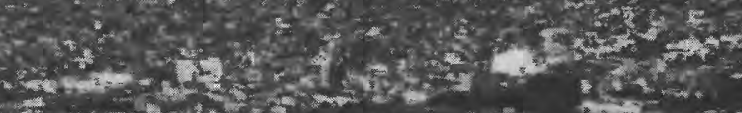

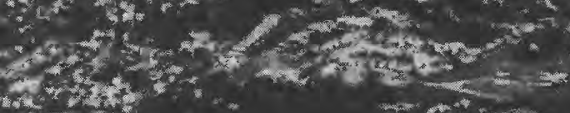

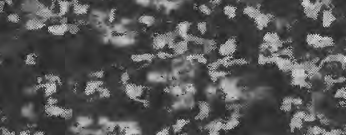

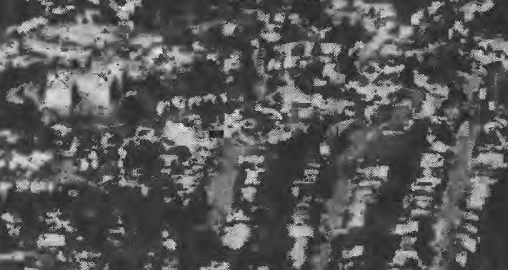

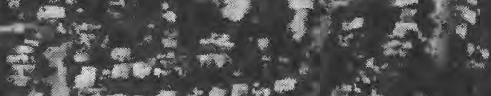


COVER:

Looking northwest along the Hayward fault zone from Oakland to Berkeley, Calif. Lake Temescal in middle foreground, San Francisco Bay in background. Photograph courtesy Clyde Sunderland, aerial photographer, Oakland. 
TECTONIC CREEP IN THE HAYWARD FAULT ZONE

CALIFORNIA 


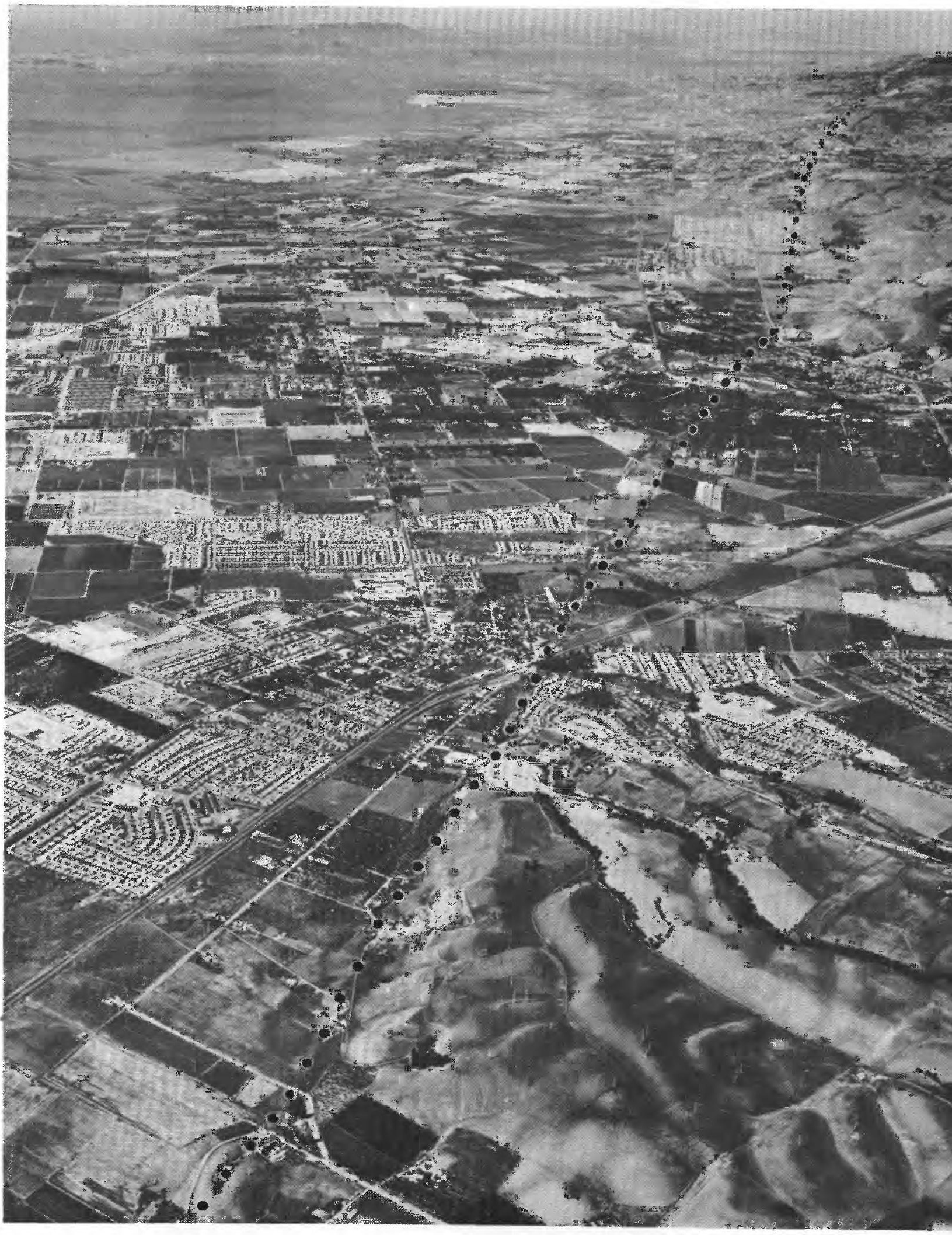

View looking northwest along the Hayward fault zone (dotted), Fremont to Oakland. Irvington district of rremont in toreground, Jan rrancisc Bay in background. Photograph courtesy Clyde Sunderland, aerial photographer, Oakland. 


\section{Tectonic Creep in the Hayward Fault Zone California}

INTRODUCTION

By Dorothy H. Radbruch and M. G. Bonilla

DAMAGE TO CULVERT UNDER MEMORIAL STADIUM UNIVERSITY OF CALIFORNIA, BERKELEY

By Dorothy H. Radbruch and Ben J. Lennert, Lennert and Associates

CRACKS IN THE CLAREMONT WATER TUNNEL

By F. B. Blanchard and C. L. Laverty, East Bay Municipal Water District

DEFORMATION OF RAILROAD TRACKS IN FREMONT, CALIFORNIA By M. G. Bonilla

CREEP IN THE IRVINGTON DISTRICT, FREMONT, CALIFORNIA

By Lloyd S. Cluff, Woodward-Clyde-Sherard and Associates and Karl V. Steinbrugge, Pacific Fire Rating Bureau

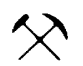

Geological Survey Circular 525 
United States Department of the Interior

WALTER J. HICKEL, Secretary

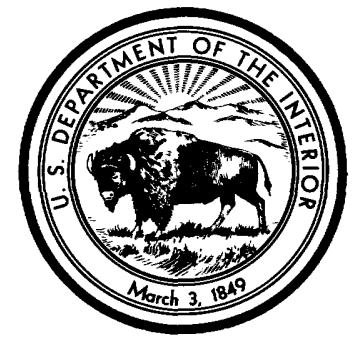

Geological Survey

William T. Pecora, Director

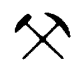

First printing 1966

Second printing 1966

Third printing 1966

Fourth printing 1968

Fifth printing 1970

Free on application to the U.S. Geological Survey, Washington, D.C. 20242 


\begin{tabular}{|c|c|c|c|}
\hline \multicolumn{3}{|c|}{ Page } & \multirow[t]{2}{*}{ Page } \\
\hline Abstract & 1 & Deformation of railroad tracks in & \\
\hline Introduction & 1 & Fremont, California & \\
\hline Damage to culvert under Memorial & & Creep in the Irvington district, & \\
\hline Stadium, University of California, & & Fremont, California & \\
\hline Berkeley _. & 3 & 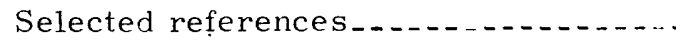 & \\
\hline Cracks in the Claremont water tunnel... & 6 & & \\
\hline
\end{tabular}

\section{ILLUSTRATIONS}

Frontispiece. View looking northwest along the Hayward fault zone, Fremont to Oakland. Figure 1. Index map showing location of Hayward, San Andreas, and Calaveras fault zones and approximate boundaries of figure 2 .

2. Map showing approximate location of fault traces of the Hayward fault zone and lncalities where evidence of creep has been found ketch map showing location of University of California Memorial Stadium, Berkeley; fault or shear zone within the Hayward fault zone; two Strawberry Creek culverts, with station designations on culverts; and location of major cracking of stadium culvert ...

4. Sketch indicating general relationship of fault to damaged culvert under the University of California Memorial Stadium, relative direction of movement of opposite sides of fault, and nature of damage to culvert

5. Map showing zone of principal deformation of Western Pacific and Southern

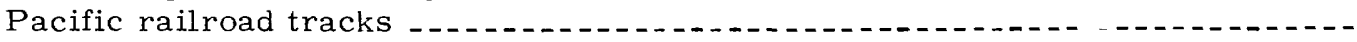

6. Photographs showing deformation of Southern Pacific siding by creep on the Hayward fault

7. View westward along Western Pacific tracks showing deformation of rails by creep on the Hayward fault

8. View looking southeast along strike of the Hayward fault zone near Irvington district, Fremont _...

9. View looking southeast along strike of Hayward fault, showing sag pond along the trace of the fault and a building extending into the fault zone

10. Line drawing showing general configurations of damaged building and nearby offset fence-....... 11

11. View looking northeast and almost perpendicular to strike of fault inside building straddling fault ......... 11

12. View looking west and nearly perpendicular to fault along inside south wall of building 


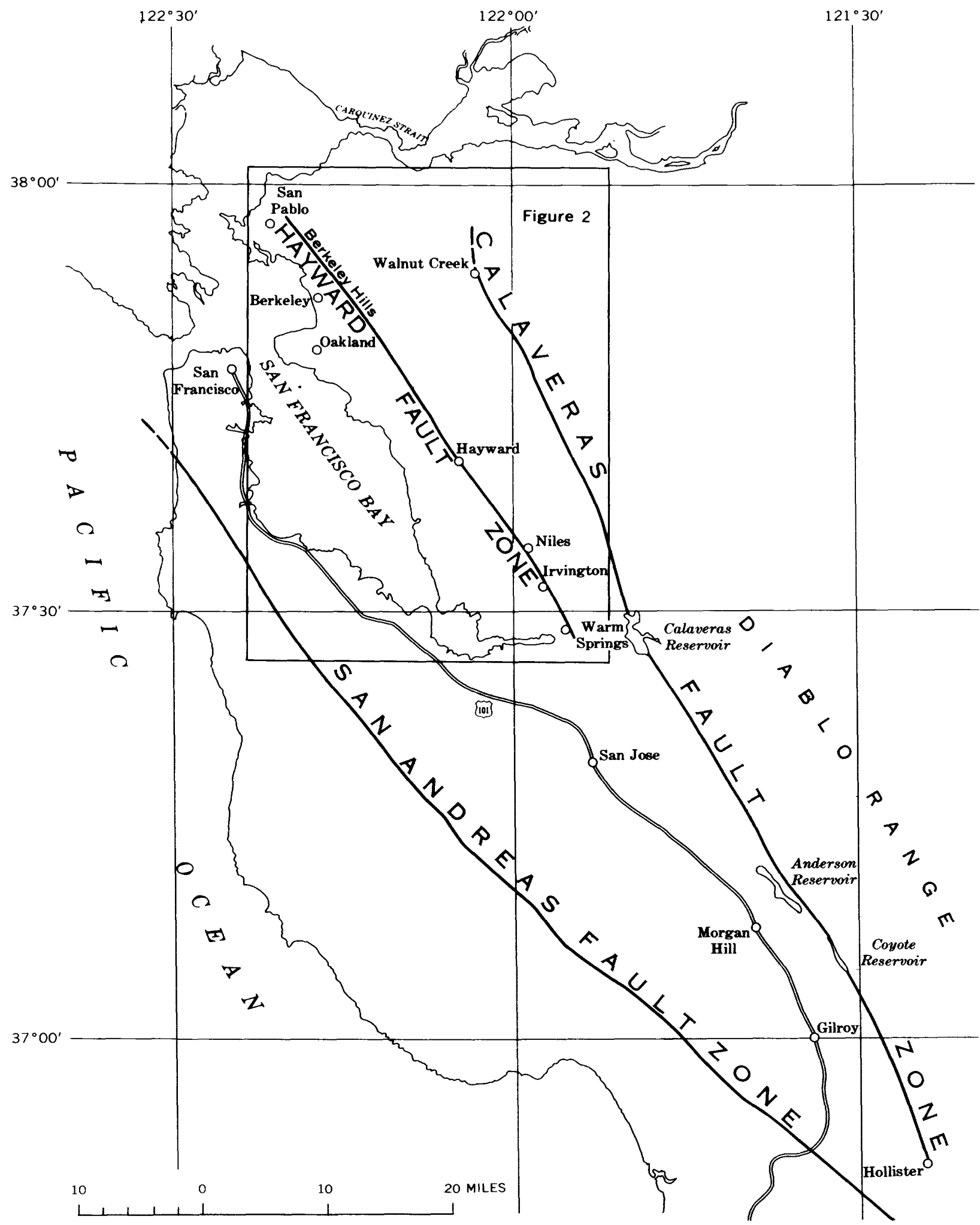

Figure 1.-Location of Hayward, San Andreas, and Calaveras fault zones, and approximate boundaries of figure 2. The towns of Niles, Irvington, and Warm Springs are now districts within the larger town of Fremont. 


\section{Tectonic Creep in the Hayward Fault Zone California}

\section{ABSTRACT}

Tectonic creep is slight apparently continuous movement along a fault. Evidence of creep has been noted at several places with in the Hayward fault zone-a zone trending northwestward near the western front of the hills bordering the east side of San Francisco Bay.

D. H. Radbruch of the Geological Survey and B. J. Lennert, consulting engineer, confirmed a reported cracking of a culvert under the University of California stadium.

F. B. Blanchard and C. L. Laverty of the East Bay Municipal Utility District of Oakland studied cracks in the Claremont water tunnel in Berkeley.

M. G. Bonilla of the Geological Survey noted deformation of railroad tracks in the Niles district of Fremont. Six sets of tracks have been bent and shifted.

L. S. Cluff of Woodward-Clyde-Sherard and Associates and K. V. Steinbrugge of the Pacific Fire Rating Bureau noted that the concrete walls of a warehouse in the Irvington district of Fremont have been bent and broken, and the columns forced out of line.

All the deformations noted have been right lateral and range from about 2 inches in the Claremont tunnel to about 8 inches on the railroad tracks. Tectonic creep almost certainly will continue to damage buildings, tunnels, and other structures that cross the narrow bands of active movement within the Hayward fault zone.

\section{INTRODUCTION}

BY DOROTHY H. RADBRUCH AND M. G. BONILLA

Tectonic creep has recently been recognized in the Hayward fault zone (fig. 1). Tectonic creep is here considered to be slight apparently continuous movement along a fault, usually not accompanied by felt earthquakes; it has also been called slippage (Whitten and Claire, 1960). Much construction is going on in the areas of creep, and the probability of damage due to slow movement of faults, in addition to the possibility of sudden rupture, should be brought to the attention of persons concerned with design, construction, or maintenance of structures in the Hayward fault zone.
The Hayward fault zone is a northwesttrending zone of faults near the western front of the hills bordering the east side of San Francisco Bay (fig. 2). It extends southeastward from San Pablo to Warm Springs, and possibly even farther both northwestward and southeastward. The zone in which recent movement has taken place ranges in width from approximately 500 feet south of Lake Temescal to about 1-3/4 miles near the Mission San Jose district. Many of the faults within the zone are actually bands of sheared rock, tens or possibly even hundreds of feet wide, in which are many anastomosing fault surfaces.

In places the surface expression of the many faults within the fault zone is very obvious. Near San Pablo the course of a fault is indicated by a short valley southeast of the Mira Vista Country Club; near the University of California in Berkeley and at Decoto the steep westward-facing front of the hills is probably a fault scarp. Lake Temescal in Oakland lies in a pronounced trench which shows the course of the fault zone, and between Niles and Irvington the main fault trace is marked by two conspicuous sag ponds. In general, the extent of the zone is indicated by such geomorphic features as shutter ridges, off set streams, lines of springs, scarps, and sag ponds.

In historic time, movements within the fault zone have caused two major earthquakes with accompanying surface ruptureone in 1836 and one in 1868 (Wood, 1916)-and numerous small shocks (Tocher, 1959). Both horizontal and vertical movement were reported at the time of the 1868 shock.

During the last few years evidence of tectonic creep along the Hayward fault zone has 


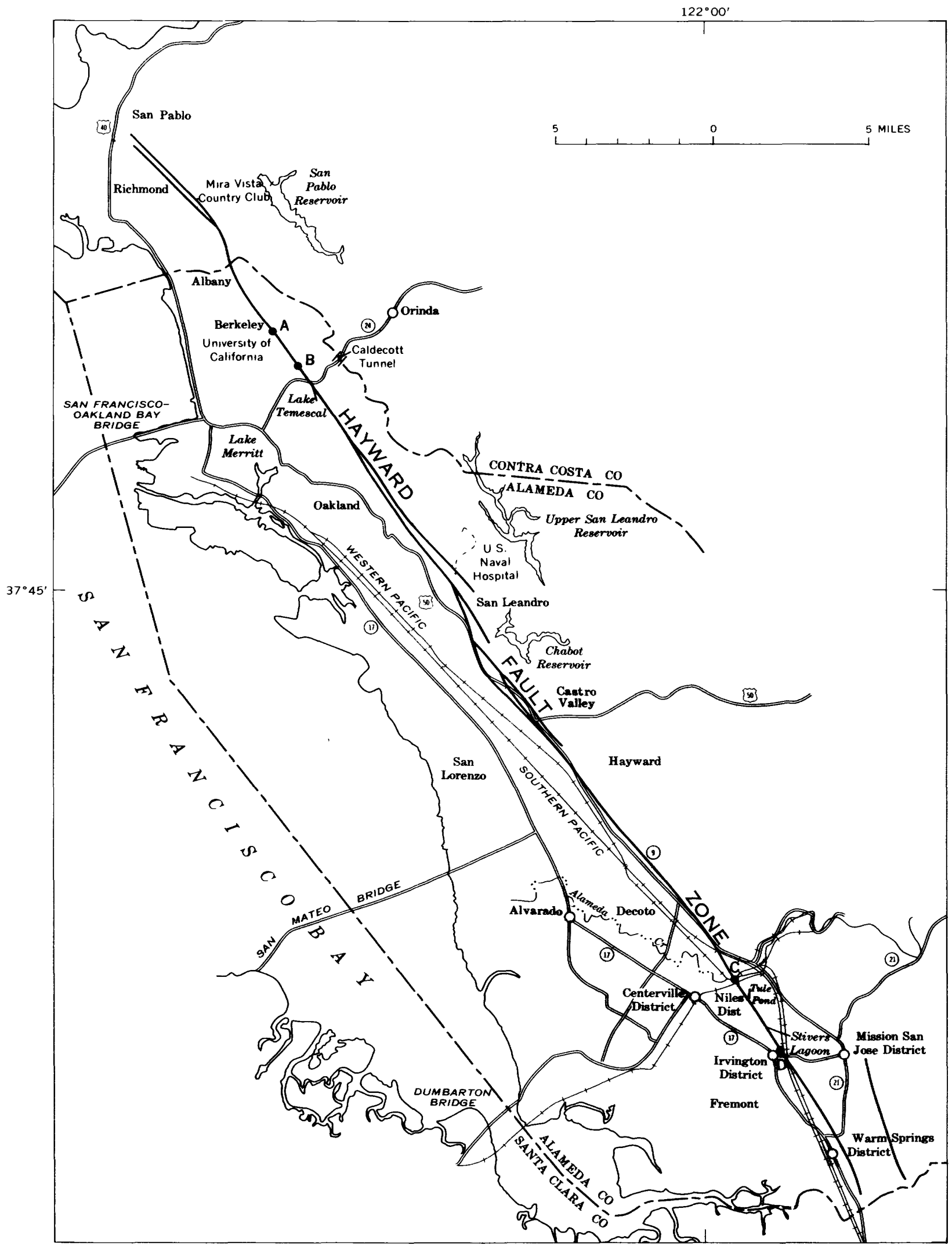

Figure 2.-Approximate location of fault traces of the Hayward fault zone and localities (A-D) where evidence of creep has been found. 
been found independently by several people from different organizations. In 1960, L. S. Cluff of Woodward-Clyde-Sherard and Associates noted distortion of a warehouse (loc. D, fig. 2) in the Irvington district of Fremont. In December 1964 the East Bay Municipal Utility District found offsets in the Claremont water tunnel (loc. B, fig. 2) in Berkeley while the tunnel was temporarily drained. In March 1965 M. G. Bonilla of the U.S. Geological Survey found distortion in railroad tracks (loc. C, fig. 2) in the Niles district of Fremont. More recently, D. H. Radbruch of the U.S. Geological Survey and Ben J. Lennert, consulting engineer, confirmed a reported cracking of the culvert (loc. A, fig. 2) under the University of California stadium in Berkeley. In each area the movement has been right lateral; that is, the northeast side of the fault has moved southeastward with respect to the southwest side of the fault.

As may be seen from figure 2, these four areas are near the ends of a 28-mile segment of the Hayward fault zone, but creep may be occurring in the intervening reaches. It is hoped that publicizing this phenomenon will encourage others to look for similar movements in other parts of the zone.

Faults do not suddenly change their habits, and therefore additional major earthquakes and tectonic creep along the Hayward fault zone can be expected. Future movement will probably take place within the fairly narrow band where historic movement and present creep are known. Direct injury to persons as a result of creep is not likely, but creep may progressively weaken structures which could fail and cause injuries.

The recognition, by geologic studies, of narrow bands of active movement permits (1) concentration of measurement for scientific and practical uses, and (2) precautions to minimize the destructive effects of the movement.

The following sections of this circular describe in detail, from north to south, the four areas of creep that have thus far been observed.

\section{DAMAGE TO CULVERT UNDER MEMORIA. STADIUM, UNIVERSITY OF CALIFORNIA, BERKELEY}

\section{BY DOROTHY H. RADBRUCH AND BEN J. LENNERT ${ }^{1}$}

The Hayward fault zone has long been known to extend northwestward across the campus of the University of California at Berkeley (Buwalda, 1929; G. D. Louderback, unpub. data). The University of California Memorial Stadium lies directly on the fault zone, its long axis being roughly parallel to it, at a spot where right-lateral movement along a sheared band or fault plane has offset the southwest-trending canyon of Strawberry Creek. The southwest side of the fault has moved northwest with respect to the northeast side, so that the downstream part of Strawberry Creek is now northwest of the upstream part. The two parts are connected by a northwest-trending section, about 1,200 feet, which flows in a culvert under the stadium. Part of the water of Strawberry Creek is carried by a bypass culvert which extends across the fault northwest of the stadium (fig. 3).

On June 23, 1965, Dorothy H. Radbruch, of the U.S. Geological Survey, and Ben J. Lennert, of Lennert and Associates, soils engineers, consultants to the University of California, examined both of the Strawberry Creek drainage culverts.

The following description of damage to the zulverts and their history of construction, damage, and repair is derived in part from field observation and in part from correspondence, reports, and drawings kindly furnished by the Division of Architecture and Engineering of the University of California and by Walter T. Steilberg, architect, consultant to the University of California. The assistance of Mr. Steilberg and the University officials and their authorization to use the material furnished are gratefully acknowledged.

\footnotetext{
1Civil Engineer, Lennert and Associates, soils engineers, Oakland, Calif.
} 


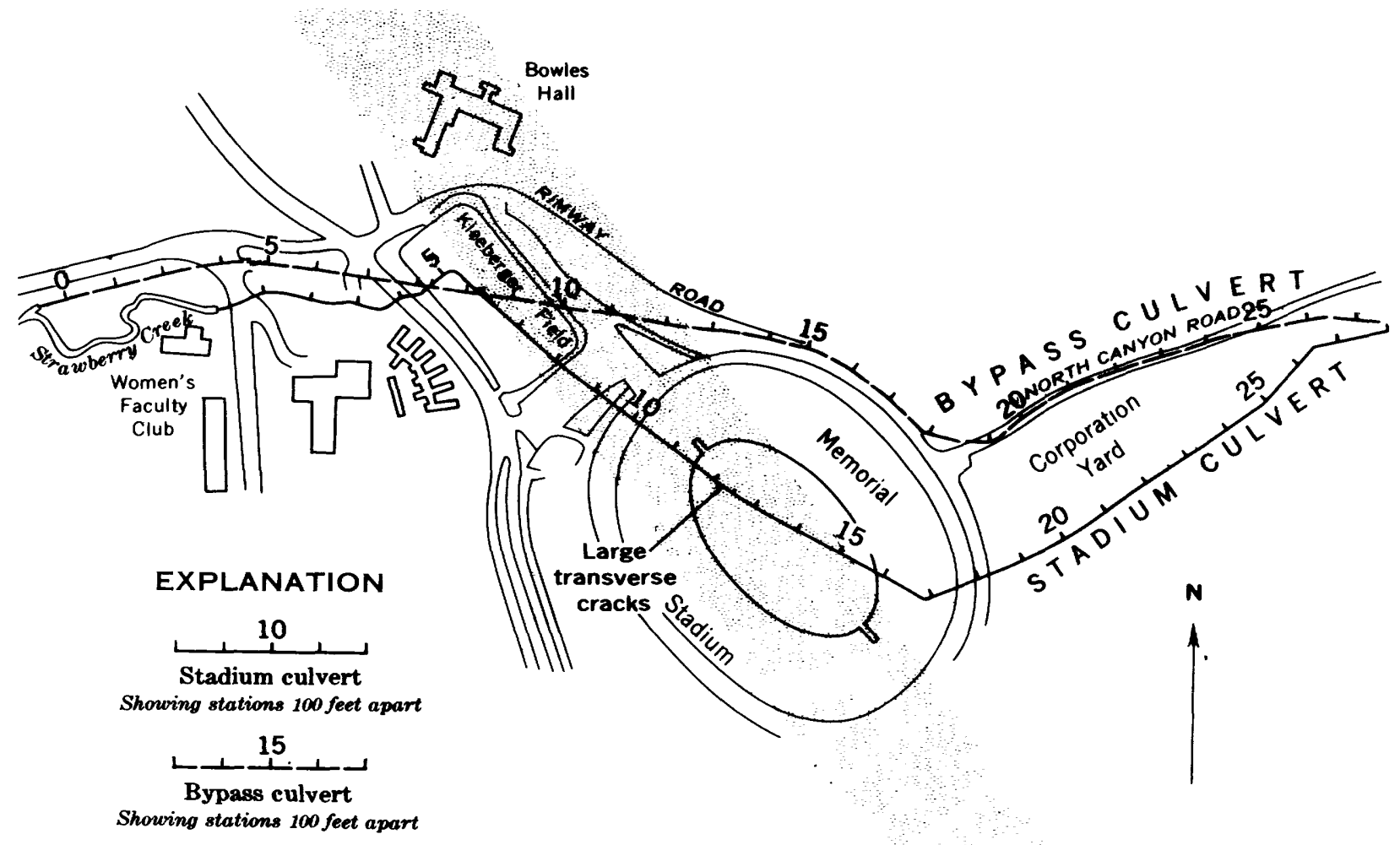

Active fault or shear zone within the Hayward fault zone (after Louderback, unpublished data)

$0,100 \quad 200 \quad 300 \quad 400500$ FEET

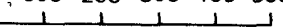

Figure 3. - Location of University of California Memorial Stadium, Berkeley, Calif.; fault o shear zone within the Hayward fault zone (stippled); two Strawberry Creek culverts, with station designations on culverts; and location of major cracking of stadium culvert.

The part of the Strawberry Creek stadium culvert which lies under the Memorial Stadium was constructed in 1923, as part of the stadium contract. It is a cast-in-place concrete box culvert 4 feet wide that ranges from 3 feet 9 inches to 4 feet in height. The original culvert extended only from what is now the Corporation Yard to a point under the present Kleeberger Field. Other sections were added later.

Minor cracks in the culvert were noted when it was first inspected in 1932. Complete records of repair at that time are not available, but it is assumed that some repairs were made. In 1948 the culvert was again inspected and was found to be in very poor condition. In addition to leaky construction joints, holes in the floor (invert), and minor cracking, two large cracks were observed at stations $12+51.5$ and $12+57$ (fig. 3 ).
The large cracks were not those mentioned in the 1932 inspection report; they were described as being 1 inch wide completely around the culvert. A notation that the cracks might be due to movement along the Hayward fault zone was made by Walter T. Steilberg on a 1948 construction drawing. Repairs consisted primarily of grouting andinstallation of mine screwjacks as temporary shores in two parts of the culvert between stations $10+50$ and $13+00$, and between stations $16+50$ and $17+50$. The two large cracks were filled with mortar.

In 1954 the culvert was again inspected before making more permanent repairs. According to Walter T. Steilberg (oral commun., 1965), the cracks at stations $12+51.5$ and 12+57 had widened between 1948 and 1954 . At this time much of the floor of the culvert was paved, and 40 gunite rings, 41 inches 
long and 36 inches in inside diameter, were installed to replace the screwjacks. The large transverse cracks were repaired with gunite, but no details are available regarding their exact width at the time or the precise nature of the repairs.

When the culvert was inspected in 1965, the damage consisted of some leaky, construction joints; erosion of the invert; hairline cracks on the northeast side of the culvert at approximately stations $8+45,9+25$, and $10+70$ and between stations $14+27$ and $15+80$; and two major cracks at approximately stations $12+50$ and $12+55$. There is no doubt that the latter two cracks are the same as those previously recorded at stations $12+51.5$ and $12+57$.

The northwest (downstream) major crack, at about station $12+50$, trends approximately at right angles to the culvert walls; in 1965 it had a maximum width of $1-1 / 4$ inches in the floor and a maximum width of $3-1 / 2$ inches on the northeast side of the ceiling, between the centerline and the junction with the wall. The southeastern (upstream) crack, which has a sinuous trend across the floor, showed a maximum gap of a quarter of an inch in the floor and a maximum width of $2-3 / 4$ inches on the southwest side of the wall. No lateral or vertical displacement of the cracks was apparent; the slight left-lateral offset reported in 1948 could not be confirmed. Water was pouring from the ceiling at both cracks, and the sides of the cracks and the walls near the cracks were coated with iron-stained calcium-carbonate, undoubtedly deposited by water entering the culvert through the cracks.

It can be assumed that the cracking of the floor has taken place since the floor was paved in 1954. The total average widening of the two cracks in the floor has been about 1.25 inches in 11 years, approximately 0.11 inch per year.

The main area of cracking and repairstations $10+50$ to $13+00$ - is thought to lie within an active sheared band or fault which is part of the Hayward fault zone (G. D. Louderback, unpub. data). The general trend of the fault probably crosses the culvert at an angle of about $20^{\circ}$. Right-lateral movement along this fault has taken place, as evidenced by the offsetting of Strawberry Creek. Right-lateral movement along the active zone would exert tension on the culvert, and tension cracks would be expected in the walls of the culvert. The formation and constant widening of the cracks that have been observed have probably resulted from such tensile stresses, and do not provide a direct measure of total movement on the fault since the culvert was installed.

No measurable lateral or vertical displacement of the cracks was observed, but the culvert appears to be slightly deflected laterally in the area of the two major cracks (fig. 4). Detailed measurements have not yet been made.

The Strawberry Creek bypass culvert, which carries part of the waters of Strawberry Creek north of the stadium, was constructed in 1954. G. D. Louderback (unpub. data), who was a consulting geologist for the architect in charge of construction, was of the opinion that two main faults or branches of the Hayward fault zone extend northwest across the campus, one lying under the stadium, and the other perhaps 400 to 500 feet farther west. He recommended that the section of the bypass culvert which would cross the easternmost fault be made of precast sections 4 feet in length, rather than the 8foot sections used for the rest of the culvert. According to Walter T. Steilberg, architect (oral commun., 1965), weak mortar was used between the 4-foot sections, so that any failure in this area would take place along the joints rather than damaging the pipe sections. Construction plans show that the 4foot sections were installed from station $7+96$ to station $15+50$, as given on figure 3 , or a distance of 754 feet.

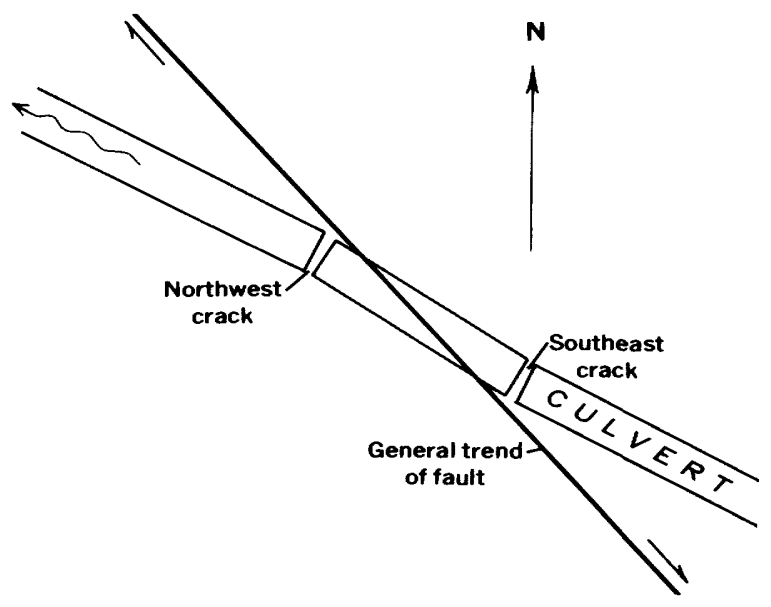

Figure 4.-General relationship of fault to damaged culvert under the University of California Memorial Stadium, relative direction of movement of opposite sides of fault, and nature of damage to culvert (not to scale). 
When the culvert was inspected in 1965, minor cracking was observed in many joints throughout the length of the culvert. The most pronounced and numerous cracks, some as much as one-eighth of an inch wide, were between stations $8+00$ and $9+00$, and between stations $10+80$ and $12+80$. The localities lie within the area thought to be crossing the active part of the fault. It is also in a place where the culvert slopes steeply, and all or part of the cracking in this area could be due to downslope movement of the pipe.

Maintenance personnel of the university report recurrent trouble with utilities, such as bending or breaking of conduit, on the rimway road near the playfield north of the stadium; the exact location is unknown at present.

Although the cracks in the stadium culvert could be due to a number of causes, such as weight of overlying fill or downslope creep of fill, it seems more probable that they are due to movement along a fault or belt of shearing within the Hayward fault zone. The major cracking of the stadium culvert, the most extensive cracking of joints of the bypass culvert, and the location of reported difficulties with utilities all lie in a northwest-trending band that is coincident with the probable location of the fault.

Since the stadium culvert was installed, there has been one earthquake (in 1937) severe enough to crackwalls and fell chimneys in the Berkeley area, as well as numerous lesser shocks (Byerly, 1951). None of them were accompanied by any visible surface rupture. Damage to the culverts is therefore probably due to slow movement or creep along the fault, with the possible exception of a small sudden movement in 1937. Records show that widening of the tension cracks in the stadium culvert has been constant, although we do not know whether it has been continuous or in small increments. Moreover, it is not possible to tell whether movement has been along one plane or distributed in a wide zone.

Preliminary observations indicate that the stadium culvert has been slightly offset in a right-lateral direction. This apparent rightlateral deflection is consistent with direction of creep noted elsewhere on the fault.

\section{CRACKS IN THE CLAREMONT WATER TUNNEL}

BY F. B. BLANCHARD ${ }^{2}$ AND G. L. LAVERTY ${ }^{3}$

Three circumferential cracks in the monolithic reinforced concrete lining of the Claremont water tunnel, each exhibiting right-lateral displacement, where observed on December 1, 1964, at a point about 900 feet from the west portal of the tunnel. The cracks occurred about 8 feet apart in a 16foot section and each showed a horizontal displacement estimated to be about threefourths of an inch. The westerly crack had slime in it and appeared to be older than the other two.

The tunnel, constructed in the 1920's, was last inspected in 1950, when no cracks were observed at this point. The location of the cracks was determined by pacing from the portal and is not precise. On the basis of the paced distance, the map-scaled location is lat $37^{\circ} 51^{\prime} 18^{\prime \prime} \mathrm{N}_{\text {., long }} 122^{\circ} 14^{\prime} 08^{\prime \prime} \mathrm{W}_{\text {., close }}$ to or within the area usually designated as the Hayward fault zone. At this point the tunnel is approximately 150 feet beneath the surface of the ground.

The Claremont water tunnel has a 9-foot horseshoe section and is one of five major facilities in the water system of the East Bay Municipal Utility District taking water from the east side of the Berkeley Hills to Berkeley, Oakland, and other cities on the east side of San Francisco Bay. After the December 1964 inspection, the tunnel was immediately refilled and placed back in service. Another inspection is planned for the winter of 1965-66.

\section{DEFORMATION OF RAILROAD TRACKS IN FREMONT, CALIFORNIA}

BY M. G. BONILLA

Six sets of railroad tracks in the Niles district of Fremont have been bent and shifted laterally by creep along the Hayward fault. The location of the tracks is shown on figure 2 (loc. C) and on figure 5 .

The distortion of the railroad tracks was found by the writer in March 1965 during

\footnotetext{
2Manager, Water Resources and Planning Division, East Bay Municipal Utility District, Oakland, Calif.

3Supervising Sanitary Engineer, East Bay Municipal Utility District, Oakland, Calif.
} 


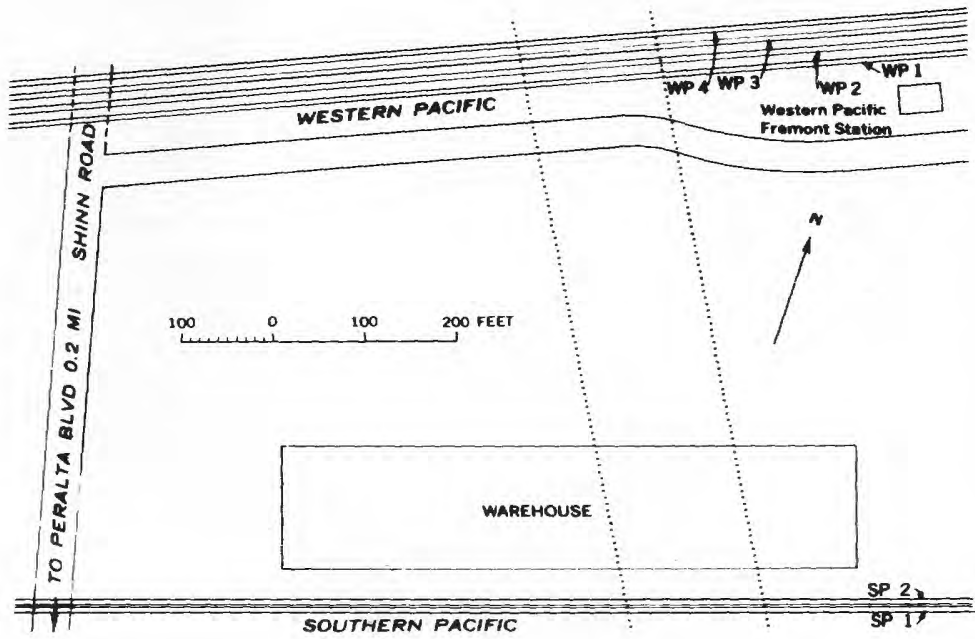

- Figure 5. - Zone of principal deformation (within dotted lines) of Western Pacific and Southern Pacific railroad track in Fremont.

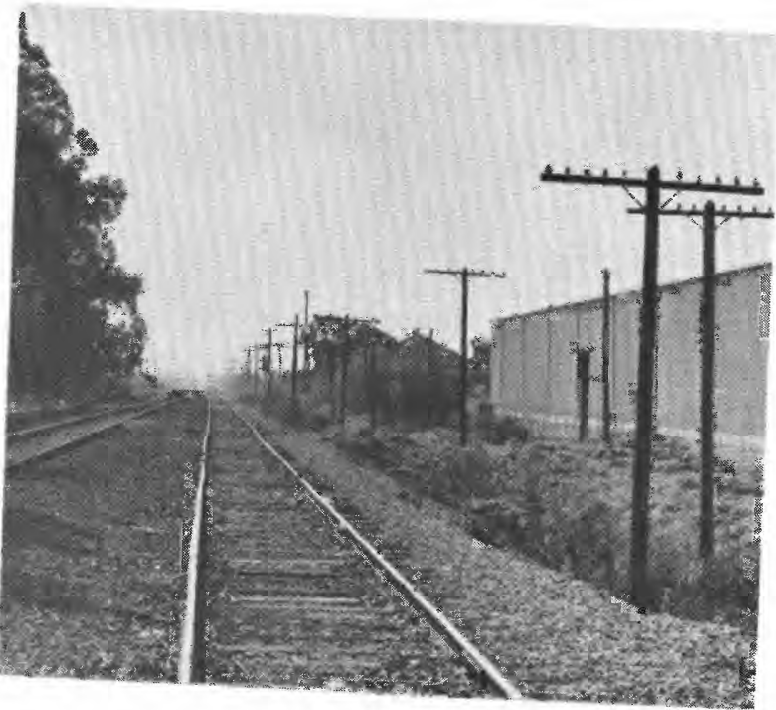

A

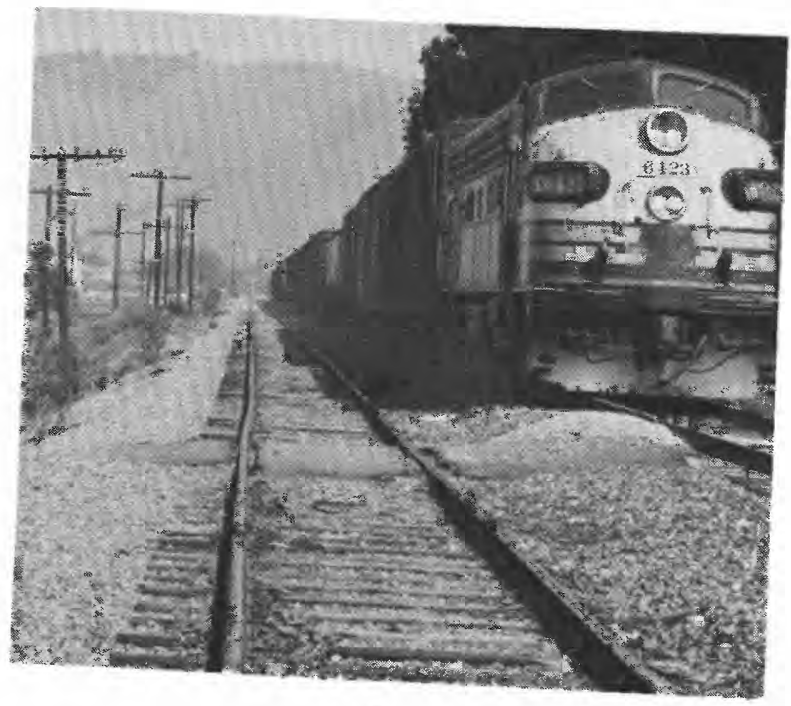

B

Figure 6. -Deformation of Southern Pacific siding by creep on the Hayward fault. A, View westward; note new warehouse on right side. $B$, View eastward. geologic mapping of a segment of the Hayward fault zone coincident with his examination of geologic evidence for recent and continuing movement along the fault. This research was supported in part by the U.S. Atomic Energy Commission.

Surface expression of the Hayward fault on the low alluvial fan upon which the tracks are built consists of linear depressions, scarps, and tonal differences in the soil visible on aerial photographs. Below the surface the fault forms an impermeable zone which results in a much higher ground-water level on the east side of the fault than on the west side, as indicated by wells close to both sides of the fault zone (Clark, 1915). Use of these criteria indicated, within narrow limits, the active part of the Hayward fault zone and therefore where the railroad tracks should be deformed if creep were occurring along that part of the fault. Upon examination, the Southern Pacific main-line track was found to have a small deflection where the projected trend of this active zone crosses it and the parallel siding to have a large deflection (fig. 6). On finding this, the Western Pacific Railroad tracks about 500 feet to the north were immediately examined, and they too were found to be deformed (fig. 7) along the same trend and in the same sense (right-lateral). Projecting the fault southeastward and using the same geologic criteria, the writer independently discovered the deformed warehouse in the Irvington district; the writer was not aware that the warehouse had been observed earlier by Cluff.

The tracks are deformed in a zone several hundred feet wide, but the major part of the 


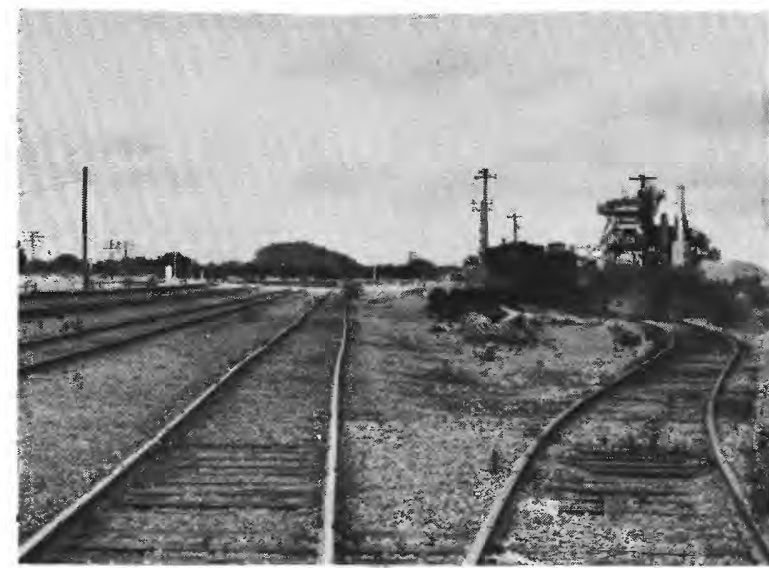

Figure 7. - View westward along Western Pacific tracks showing deformation of rails (center of photo.) by creep on the Hayward fault. Curve in tracks on right side is not the result of creep.

deformation is in a narrower zone (stippled on fig. 5). The deformation is moderately sharp on the sidings and yard tracks (figs. 6 and 7) but is smooth and difficult to see on the main-line tracks, owing to more frequent maintenance and heavier and faster traffic that tends to remove irregularities. The sharpest bends show a lateral shift of about 4 inches in 70 feet (fig. 6) and 6 inches in 60 feet (fig. 7). No vertical movement has been detected.

The rate of movement is evidently variable. The main-line Southern Pacific and Western Pacific tracks, first laid about 55 years ago, both show a total shift of about 8 inches, or an average rate of shift of more than 0.14 inches per year. The rate must vary greatly, however, as lateral shifts of as much as $1-1 / 2$ inches within a period of 2 or 3 days were reported by D. J. Laughlin (Western Pacific Railroad, oral commun., 1965), who said that the rapid movements apparently do not coincide with local earthquakes.

The warehouse just north of the Southern Pacific tracks, shown on the map (fig. 5) and on the right side of figure $6 \mathrm{~A}$, was completed in 1964. No deformation resulting from creep was visible in March 1965.

\section{CREEP IN THE IRVINGTON DISTRICT, FREMONT, CALIFORNIA}

BY LLOYD S. CLUFF ${ }^{4}$ AND KARL V. STEINBRUGGE 5

Evidence for fault creep has been found along a 3-mile section of the active Hayward

${ }^{4}$ Chief Engineering Geologist, hoodward-Clyde-Sherard and Associates, Oakland, Calif.

5Structural Engineer, Pacific Fire Rating Bureau, San Francisco, Calif. fault zone in the Irvington district Fremont, Calif.

Damage to a one-story storage building and to at least one offset fence astride the Hayward fault zone in the Irvington district of Fremont indicates that at least 6 inches of right-lateral movement has occurred on the fault within the last 44 years.

This paper presents only partial information on the 3-mile section from Alameda Creek south to Washington Boulevard in the Irvington district and discusses mainly a building that shows distinct evidence of right-lateral movement. A more detailed account of these studies will be presented in a forthcoming issue of the Bulletin of the Seismological Society of America.

Topographically, the area in the vicinity of the damaged storage building is relatively flat land on which the traces of faults in the Hayward fault zone are marked by fault scarps ranging from 3 to approximately 30 feet in height, shallow depressions that form linear troughs 200 to 300 feet wide and 5 to 10 feet deep, and sag ponds (figs. 8 and 9). These features are considered to be the result of successive movements along the fault during geologic and historic times.

Geologically, the building is near the outer limits of a broad alluvial fan, the Niles cone, which has been deposited by Alameda Creek between San Francisco Bay and the hills bordering the bay on the east. The fan is composed of layered deposits of gravel, sand, silt, and clay. The Hayward fault zone cuts through the alluvial deposits, and in places clay gouge formed along fault planes has created a ground-water barrier which produces different water levels on either side of the fault (Clark, 1915; Forbes, 1949).

During the course of geologic field mapping along the Hayward fault in November 1960, the senior author discovered a damaged one-story storage building extending partly into the fault zone. A detailed inspection of the building showed that the damage was concentrated in the part of the building which lies along the northwest-trending fault zone and consisted of fractures, cracks, deflections, bends, and offsets, all of which indicated right-lateral movement. In checking the seismic history of the Fremont area, it was found that no earthquakes were recorded which appeared to have a magnitude strong enough to produce ground breakage along 


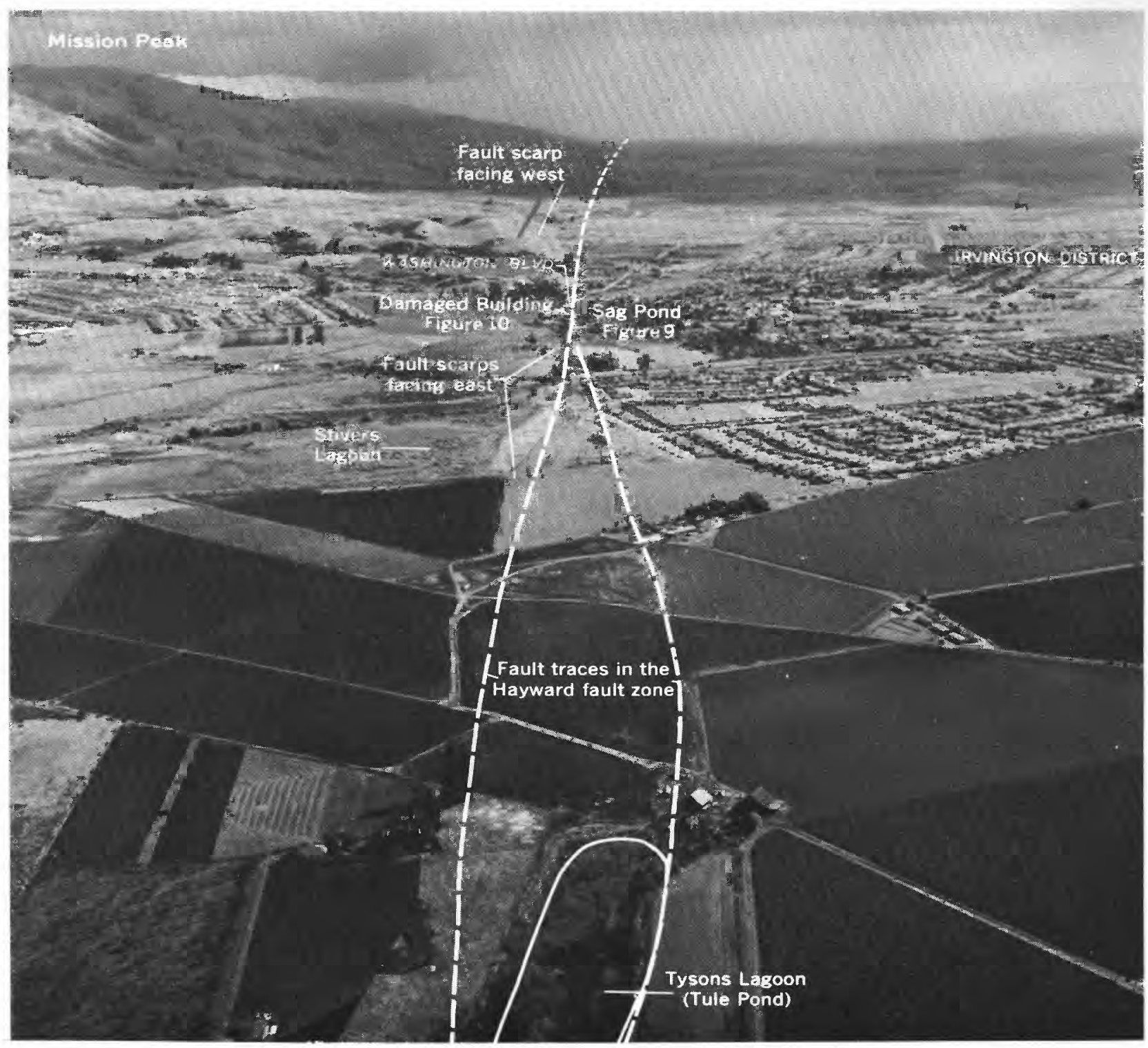

Figure 8. -View looking southeast along strike of the Hayward fault zone near Irvington district, Fremont, Calif.

the Hayward fault zone during the lifetime of this building. Local residents have no knowledge of earthquakes associated with fault movement since 1868.

The main building (fig. 10) was erected in 1921 , according to local residents. The building has nonreinforced concrete walls, a wood roof, and a concrete floor slab most of which is on grade. Most of the main building is on the southwest side of the Hayward fault zone which trends northwest through the northeast part of the main building (fig. 10).

The floor slab in the northeast part of the main building, having a floor area of about 60 by 200 feet, has been cracked and offset along a crack so that the northeast part of the slab appears to have moved 6 inches to the southeast with respect to the southwest part (fig. 11). The exterior walls, which are 10 inches thick, have been bent, broken, and offset (fig. 12); the interior and exterior columns are as much as 6 inches out of plumb (fig. 11); and the roof has bowed right laterally.

Another part of the building extending into the fault zone has a buckled basement floor slab and a buckled basement wall.

The damage to this storage building is remarkably similar to the damage at the winery 


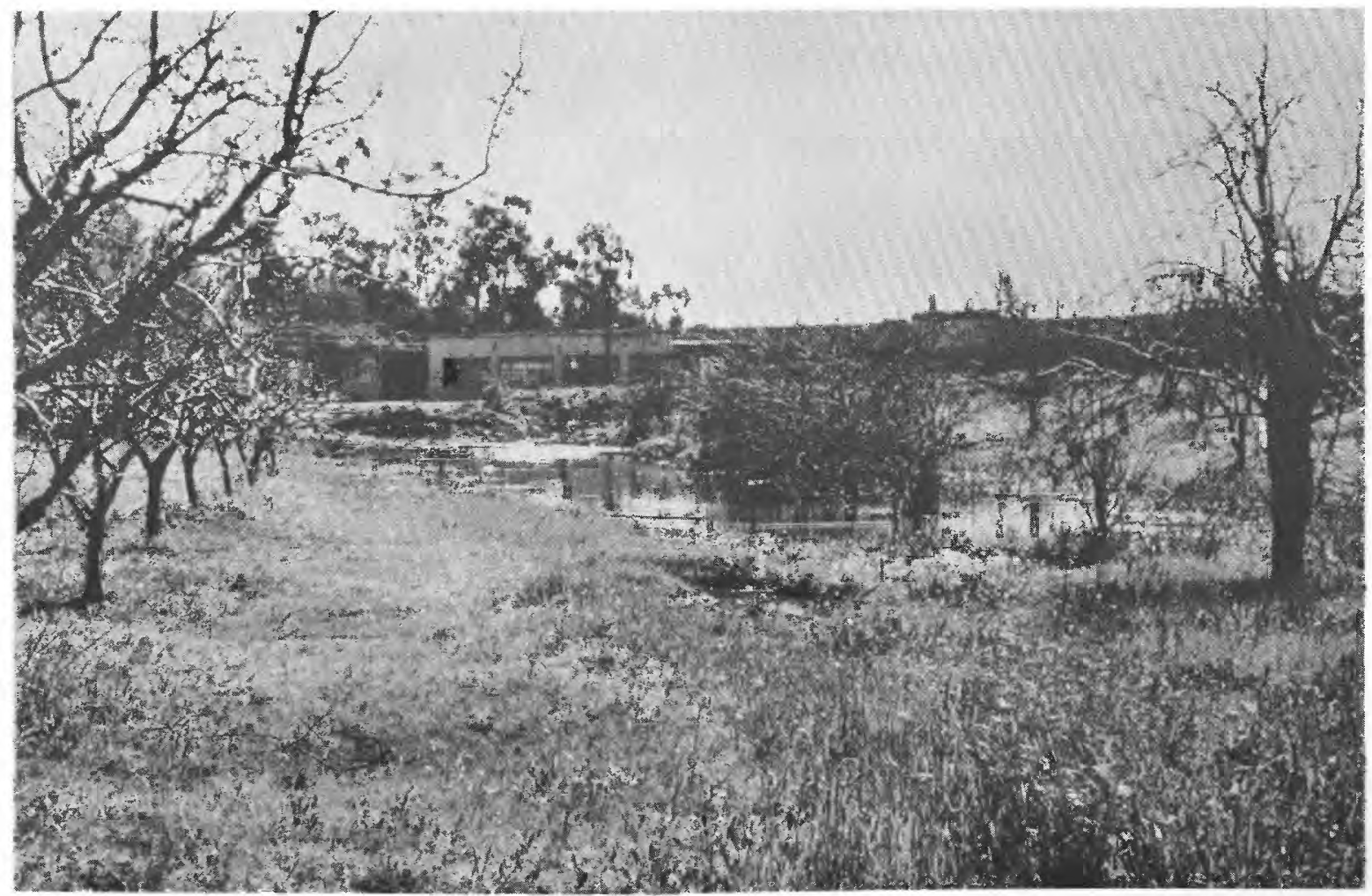

Figure 9. - View looking southeast along strike of Hayward fault, showing sag pond along the trace of the fault and a building extending into the fault zone.

straddling the active San Andreas fault near Hollister, Calif., which is being damaged by fault creep (Steinbrugge and others, 1960). The similarity of damage and the fact that both structures are astride traces of active faults suggest that fault creep was responsible for the structural damage to the building on the Hayward fault.

All the offsets and damage, when plotted on a map (fig. 10), aline parallel to the northwest strike of the Hayward fault and are within the fault zone. This damage appears to be limited to a band less than 10 feet wide and may indicate movement on a single fault plane within the Hayward fault zone; however, the width of the disturbed band may be wider. The rate of creep appears to be 6 inches in 44 years. A more complete answer will not be known until detailed studies are made.

In March 1965 the authors installed creep reference marks inside the damaged building across the displaced zone in the floor slab so that a record of further movements could be made. For the time being, this measurement system is being used to note any further creep movement along the fault. Work is in progress under the direction of the authors for permanent survey stations across the Hayward fault zone in the Irvington area.

The Hayward fault is under continuing study by the authors for several miles on each side of the damaged building. Additional evidence of movement has been observed by the authors on offset fences immediately to the north and approximately 1 mile to the northwest of the damaged building. Reference structures, such as railroads southeast of the building and large-diameter pipelines, cross the fault zone at various nearby locations. These are being observed and surveyed by the authors in hopes of obtaining additional information as to the details of this fault movement. The evidence to date suggests that most of the creep observed along the Hayward fault zone in the Irvington district (in the amount of approximately 6 in.) occurred during the period 1951 to 1957. Judging from possible effects on structures described in this report by Cluff and Steinbrugge, no measurable creep has occurred in this area since 1957. 


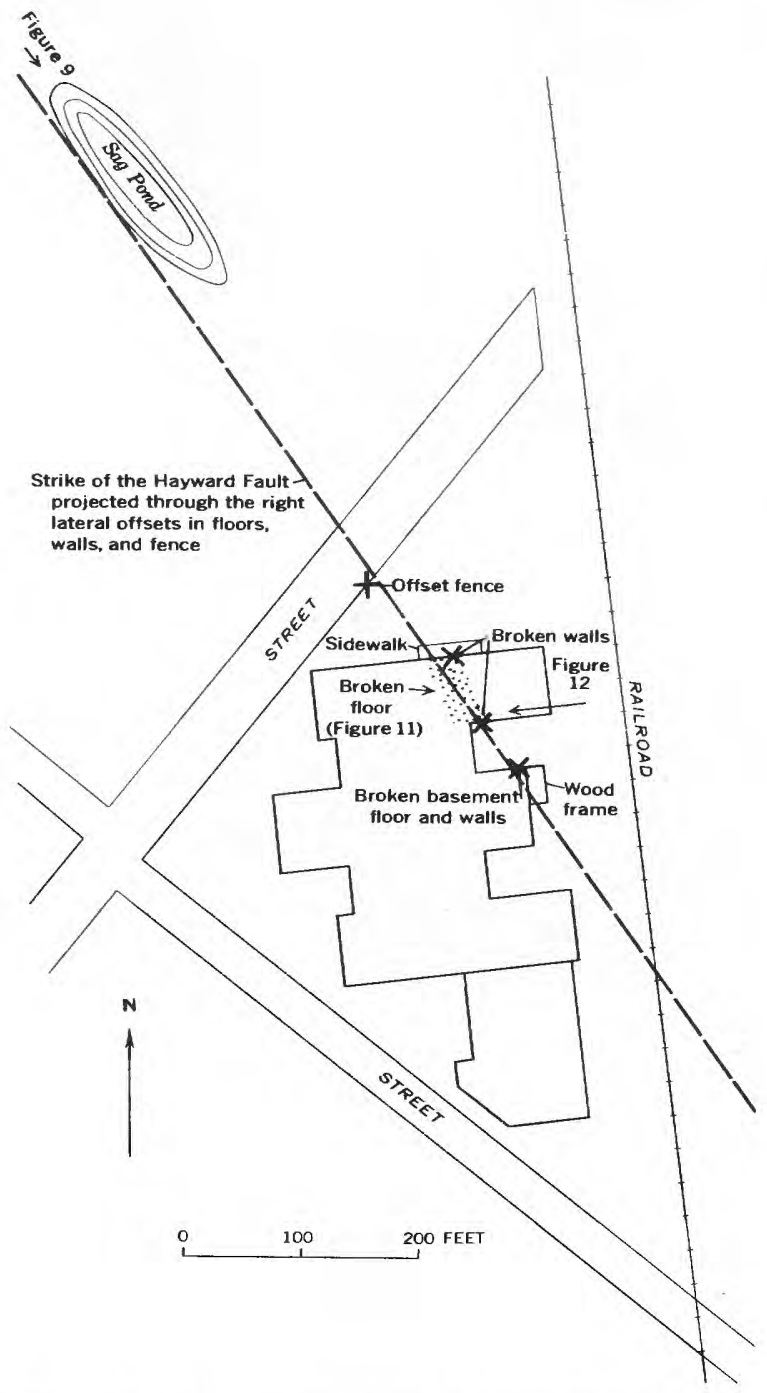

Figure 10.-General configurations of damaged building and nearby offset fence.

In summary, it may be concluded that:

1. Damage to a one-story building on the Hayward fault zone in the Irvington district of Fremont indicates that at least 6 inches of right-lateral creep has occurred on the fault zone since construction in 1921 .

2. Any structure astride an active fault is not only subject to damage resulting from sudden faulting associated with a severe earthquake, but may be damaged by a slow shearing movement along the fault.

3. Creep along an active fault is not cause for sudden alarm for it progresses slowly. However, because creep is irresistible and can be expected to continue, its location and

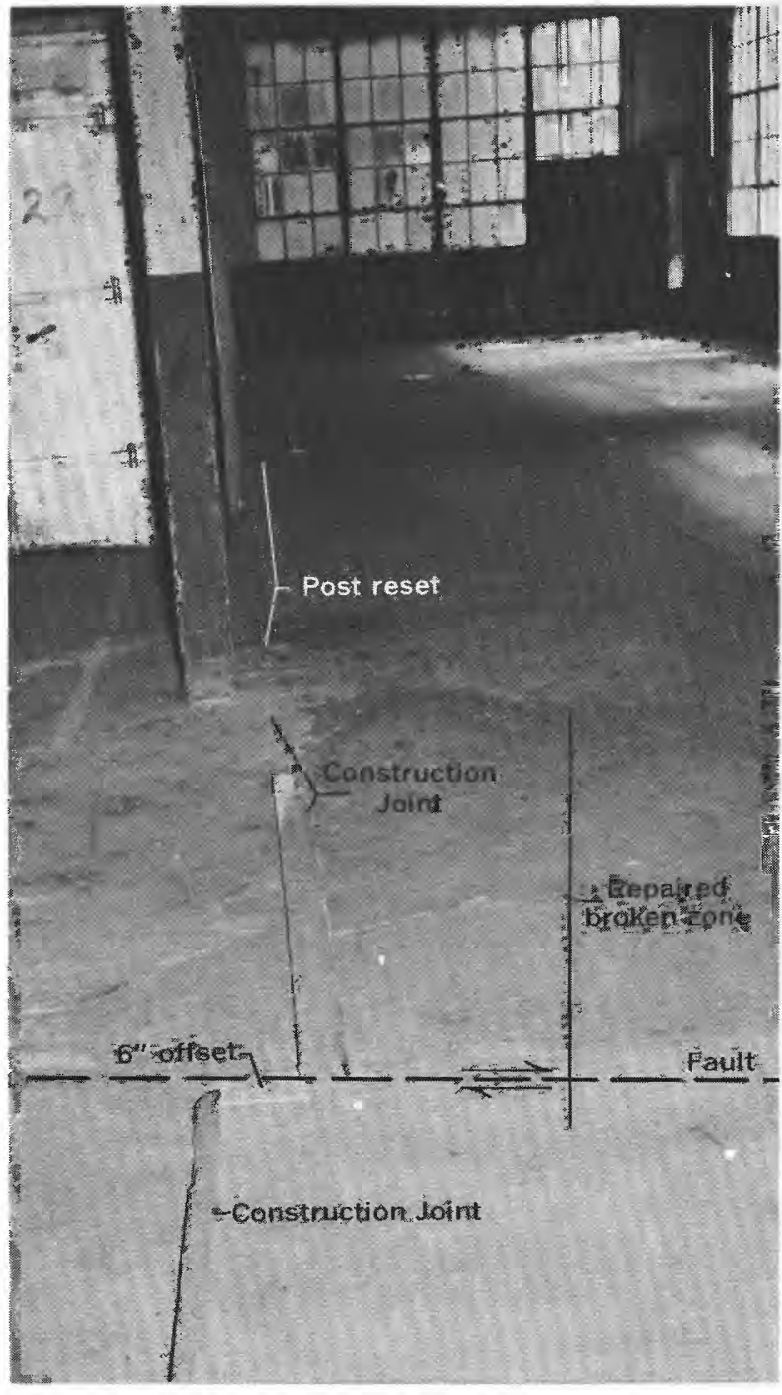

Figure 11. -View looldng northeast and almost perpendicular to strike of fault inside building straddling fault. Construction joint in floor slab has been displaced approximately 6 inches right laterally.

rate of movement should be under constant observation.

4. The significant lesson to learn is that active faults should be recognized and respected in planning of future structures, developments, and communities.

Some questions yet unanswered with respect to the time-history of the creep phenomenon are as follows:

Is the creep occurring unnoticed in short, sporadic movements associated with earthquakes? 


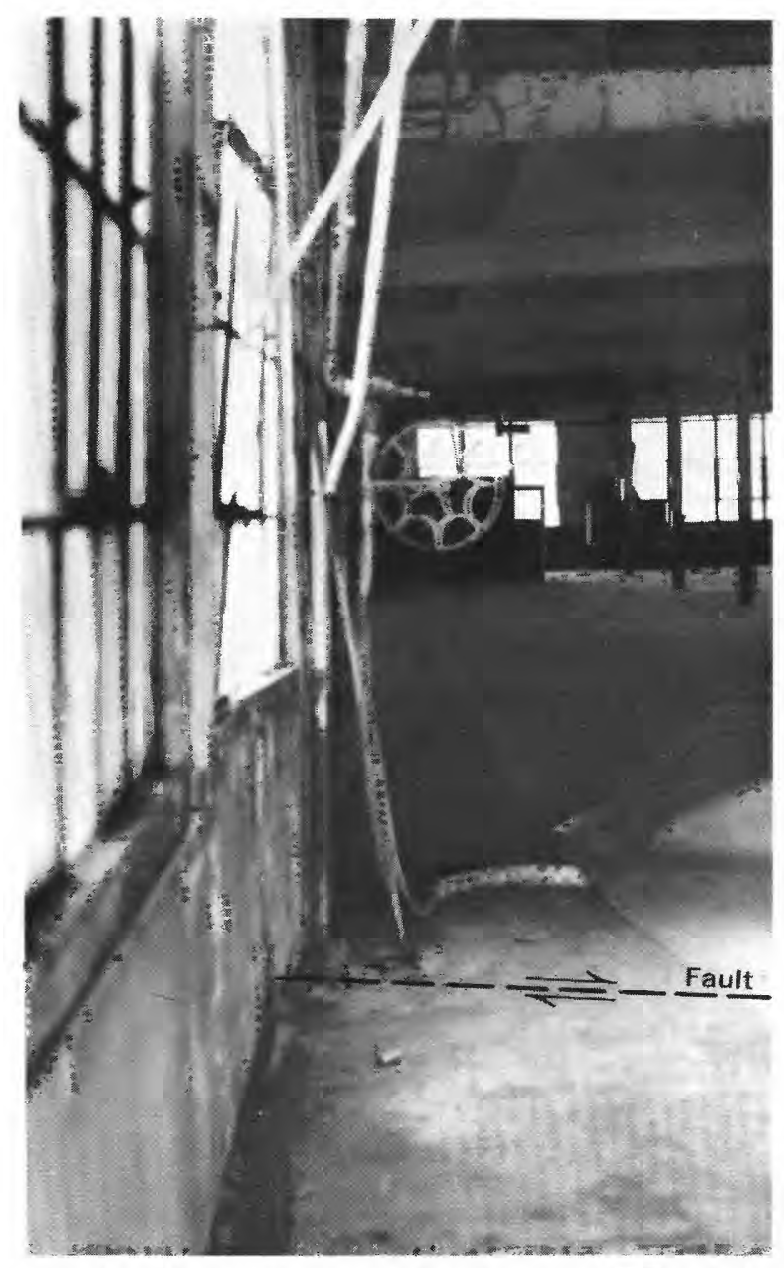

Figure 12. -View looking west and nearly perpendicular to fault along inside south wall of building.

Is the creep occurring along parallel or en echelon lines of slippage?

What are the variations of creep along tne entire length of the Hayward fault?

Does the creep indicate an accumulation of regional strain, building up to a strong earthquake in the near future, or does the creep indicate a release of accumulating regional strain indicating that a strong earthquake should not be expected in the near future?

\section{SELECTED REFERENCES}

Bailey, E. H., Irwin, W. P., and Jones, D. L., 1964, Franciscan and related rocks, and their significance in the geology of western California: California Div. Mines Bull. 183, $177 \mathrm{p}$.

Buwalda, J. P., 1929, Nature of the late movements on the Haywards rift, central Cali- fornia: Seismol. Soc. America Bull., v. 19, no. 4, p. 187-199.

Byerly, Perry, 1951, History of earthquakes in the San Francisco Bay area: California Div. Mines Bull. 154, p. 151-160.

California Department of Water Resources, 1964, Crustal strain and fault movement investigation, faults and earthquake epicenters in California: California Dept. Water Resources Bull. 116-2, 95 p.

Case, J. E., 1963, Geology of a portion of the Berkeley and San Leandro Hills, California: California Univ., Berkeley, Ph.D. thesis.

Clark, W. O., 1915, Ground-water resources of the Niles cone and adjacent areas, California: U.S. Geol. Survey Water-Supply Paper 345-H, p. 127-168.

1924, Ground water in Santa Clara Val. ley, California: U.S. Geol. Survey WaterSupply Paper 519, 209 p.

Crittenden, M. D., Jr., 1951, Geology of the San Jose-Mt. Hamilton area, California: California Div. Mines Bull. 157, 74 p.

Duke, C. M., compiler, 1958, Bibliography of effects of soil conditions on earthquake damage: San Francisco, Calif., Earthquake Eng. Research Inst., 47 p.

Duke, C. M., and Leeds, D. J., 1959, Soil conditions and damage in the Mexico earthquake of July 28, 1957: Seismol. Soc. America Bull., v. 49 , no. 2, p. 179-191.

Forbes, Hyde, 1949, Effect of Niles-Irvington section of the Haywards fault: Seismol. Soc. America Bull., v. 39, no. 4, p. 243-247.

Gilbert, G. K., Humphry, R. L., Sewell, J. S., and Soulé, F., 1907, The San Francisco earthquake and fire of April 18, 1906, and their effects on structures and structural materials: U.S. Geol. Survey Bull. 324, $170 \mathrm{p}$.

Iacopi, Robert, 1964, Earthquake country: Menlo Park, Calif., Lane Book Co., 191 p.

Lawson, A. C., 1908, The California earthquake of April 18, 1906-Report of the State Earthquake Investigation Commission: Carnegie Inst. Washington Pub. 87, v. 1, pt. 2, p. 255-451.

1914, San Francisco, California, Folio: U.S. Geol. Survey Geol. Atlas, Folio 193, 24 p. (library ed.).

Louderback, G. D., 1937, Characteristics of active faults in the central Coast Ranges of California, with application to the safety of dams: Seismol. Soc. America Bull., v. 27, no. 1, p. 1-27.

1942, Faults and earthquakes: Seismol. Soc. America Bull., v. 32, no. 4, p. 305-330. 
Louderback, G. D., 1947, Central California earthquakes in the 1830's: Seismol. Soc. America Bull., v. 37, no . 1, p. 33-74.

Radbruch, D. H., 1965, Approximate location of fault traces and historic surface ruptures within the Hayward fault zone between San Pablo and Warm Springs, California: U.S. Geol. Survey open-file rept.

Robinson, G. D., 1956, Geology of the Hayward quadrangle, California: U.S. Geol. Survey Geol. Quad. Map GQ-88.

Russell, R. J., 1926, Recent horizontal of ssets along the Haywards fault: Jour. Geology, v. 34 , no. 6, p. 507-511.

Small, J. B., 1963, Interim report on vertical crustal movement in the United States: Internat. Assoc. Geodesy, Internat. Union Geodesy and Geophysics, presented at Berkeley, Calif., August 1963, before the Commission on recent crustal movements.

Steinbrugge, K. V., Zacher, E. G., Tocher, Don, Whitten, C. A., and Claire, C. N., 1960, Creep on the San Andreas fault: Seismol. Soc. America Bull., v. 50, no. 3, p. 389-415.

Tocher, Don, 1959, Seismic history of the San Francisco Bay region, in San Francisco earthquakes of March 1957: California Div. Mines Spec. Rept. 57, p. 39-48.
Townley, S. D., and Allen, M. W., 1939, Descriptive catalog of earthquakes of the $\mathrm{Pa}-$ cific Coast of the United States, 1760 to 1928: Seismol. Soc. America Bull., v. 29, no. 1, p. 1-297.

U.S. Army, Far East Command, 1949, The Fukui earthquake, Hokuriku region, Japan, 28 June 1948: U.S. Army, Office of the Engineer, Gen. Headquarters, Far East Command, v. 1, Geology, v. 2, Engineering, $300 \mathrm{p}$.

U.S. Coast and Geodetic Survey, 1930-64, United States Earthquakes 1928-1962: U.S. Coast and Geod. Survey.

Whitten, C. A., 1955, Measurements of earth movements in California: California Div. Mines Bull. 171, p. 75-80.

Whitten, C. A., and Claire, C. N., 1960, Creep on the San Andreas fault [California]-Analysis of geodetic measurements along the San Andreas fault: Seismol. Soc. America Bull., v. 50, no. 3, p. 404-415.

Wood, H. O., 1916, California earthquakes; a synthetic study of recorded shocks: Seismol. Soc. America Bull., v. 6, p. 55-180. 